\title{
RELIGIOUS EDUCATION AND CATEHISATION
}

\author{
Andrian Aleksandrov*
}

\begin{abstract}
After 1989, the Church in Bulgaria was once again free to deliver religious education and instruction. Quite naturally, it found itself at the forefront of the fight to re-introduce the subject of religion in school. At the same time, many parish (Sunday) schools were opened. All of this necessitated the preparation of multiple documents by the Holy Synod. This article aims to present the official position of the Bulgarian Church as reflected in the synodal decisions on the subject of religious education and catechisation.
\end{abstract}

Keywords: Church, religious education, catechetics.

\section{Introduction}

The Church of Christ has three main functions administered through its pastoral ministry: 1 . Instruction in the supernatural truth of the teaching of Jesus Christ; 2. Sanctification in divine grace; and 3. Strengthening in the ways of religious and moral life ${ }^{1}$. Hence, the means of pastoral action: instruction in truth, administration of grace through the sacraments, and exercise of spiritual discipline, or, in other words: truth-grace-law.

Leaving aside grace, which God bestows upon men directly or by means of the sacraments ${ }^{2}$, and spiritual discipline ${ }^{3}$, which seeks to preserve and develop the religious and moral life of the faithful, we are going to focus on the first aspect - instruction in the truth, as administered within the Bulgarian Orthodox Church (in short - BOC) today. To this end, we will consider some key texts as a reflection of its official position.

* PhD, Professor, University of Sofia, Bulgaria.

${ }^{1}$ These three tasks were commanded by our Saviour to His disciples: Go ye therefore, and teach all ... baptising them ... teaching them to observe all things whatsoever I have commanded you ... (Matt 28:19-20).

${ }^{2}$ The sources of grace are: Scripture, prayer, the sacraments and good deeds.

${ }^{3}$ This means is called by the Church $\pi \alpha 1 \delta \varepsilon i \alpha$, lat. disciplina (cf. 2 Tim 3:16), and includes liturgical sermon, deaconical work etc. 
The Church fulfils its mission for the salvation of mankind directly through preaching and Christian education. To do this, it cooperates with the State and its institutions, however without setting out to achieve a universal conversion into Orthodoxy as a prerequisite for such cooperation. The Church holds the belief that common virtuousness will help to restore fidelity to devout moral standings, which are such a vital aspect of modern life ${ }^{4}$.

Christian faith is a firm conviction acquired through the knowledge of the Lord Jesus Christ and His teachings. Such knowledge requires an effort of the will. In the words of St Paul the Apostle: How then shall they call on him in whom they have not believed? And how shall they believe in him of whom they have not heard? And how shall they hear without a preacher? (Rom 10:14). Hence, faith necessitates learning, i.e. familiarisation with fundamental doctrinal truths, or catechisation. The latter requires regular participation in the church sacraments and services, in particular the St Eucharist. It is associated with the acceptance into the Church, both during the pre-baptismal catechesis and after the baptism of catechumens making their first steps into church life. In its narrow sense, catechisation refers to catechetical talks on the fundamentals of faith with people preparing to be baptised, or to become godparents, get married, be first witness or participate in another holy sacrament. In the broader sense, catechisation is associated with the delivery of spiritual education by the Orthodox Church among the different layers of society, aimed at the inclusion of the people into the devout norms of Christian life in its totality. ${ }^{5}$ Today, catechisation is understood as support for inclusion in church

\footnotetext{
${ }^{4}$ Concept of the Holy Synod of the BOC on the status of the subject of religion in Bulgarian schools: http://www.bg-patriarshia.bg/index.php?file=concepts_1.xml (Accesed on 15 April 2016).

${ }^{5}$ Guidelines on the implementation of the Strategy for Spiritual Education, Catechisation and Culture of the BOC <http://www.bgpatriarshia.bg/index.php?file=strategies_2.xml $>$ (Accesed on 15 April 2016).
} 
life, i.e. churching ${ }^{6}$, of those having decided in favour of it, regardless of the issue of baptism (in other words, it applies to both those wishing to be baptised and those having already been baptised). In practice, catechisation also stands for instruction into the Christian faith and fostering of evangelical morality ${ }^{7}$.

Orthodox religious education and catechisation in Bulgaria have a long and rich history, in which the modern-day Bulgarian school is a direct descendant of the church catechetical school.

Today, the BOC enjoys exceptional confidence among Bulgarian citizens $^{8}$, and Orthodox Christians are particularly sensitive to the current state of affairs in church education and culture. Therefore, in terms of the establishment of commitment and trust among all participants in church educational practices, it is advisable, necessary and vital that an open dialogue and cooperation be sought at different institutional levels within the Church. For the same reason, current decisions concerning church education need to be sustainable, clear and consistent, as well as to be able to retain

${ }^{6}$ Churching does not simply mean the acquisition of a set of intellectual knowledge and / or the attainment of various external church actions, habits and rites, but an effective participation in the sacramental life of the Church, aimed at a real transformation of the mind, manners, attitudes and the way of life of the people in accordance with the evangelical example and the image of the Person of Jesus Christ. Churching stands for the introduction of man into the Body of Christ, the adoption of graceful spiritual life, the support to establish moral and spiritual connections with the other parishioners and to become Christ in mind, manners and attitude, and thus to become a living cell of the divine-human organism which is the Church of Christ.

7 Белановский, Ю. С., Ракушин, А.В., Шестаков, А.А. Катехизация в Русской Православной Церкви на современном этапе. Учебное пособие для слушателей курсов по подготовке катехизаторов, миссионеров и церковных педагогов. М. 2007, с. 6.

${ }^{8}$ According to data from the European Values Study, the Church is the only Bulgarian institution in the survey exhibiting an increase in confidence in 2008 over 1999. In: European Value Study (4 ${ }^{\text {th }}$ wave, Bulgaria 2008) $<$ http://www.bsa-bg.org/index.php/2012-05-24-08-32-37/16-4-2008> (Accesed on 15 April 2016). 
their relevance for longer periods of time. It is further important to ensure foresight in the development of modern catechisation in Bulgaria, as well as stability of the decisions about its future practical implementation and existence. This can be achieved through a significant increase in the active participation of the clergy and the laity in modern Orthodox education and culture by guaranteeing free access and conditions for their training and further qualifications ${ }^{9}$.

In 2012, in response to the new challenges of today's dynamic world requiring a search for balance between traditional methods, forms and means of spiritual education and a flexible and adaptive development and improvement of catechetical practices, the BOC adopted a Strategy for Spiritual Education, Catechisation and Culture. During its preparation, special account was taken of the importance of church educational and cultural activities at synodal, eparchial, spiritual district, parish and monastic level. The Strategy specifically focuses on the full and effective integration of Orthodox Christians in the liturgical and social life of the parish community, as well as in the monastic, eparchial, local and catholic church communities. The concrete mechanisms for the implementation of the Strategy are further outlined and detailed in a number of other documents, such as: Concept for a Synodal Catechetical Centre of the Holy Synod of the BOC; Concept of the Holy Synod of the BOC on the status of the subject of Religion in Bulgarian schools; Comprehensive programme for planning the activities of the Culture and Education Department at the Holy Synod of the BOC; Comprehensive programme for planning the activities of the Synodal Catechetical Centre of the Holy Synod of the BOC; Guidelines on the implementation of the Strategy for Spiritual Education, Catechisation and Culture of the $\mathrm{BOC}^{10}$. In addition, the Strategy details and specifies the organisational structures, levels and positions within the Holy Synod,

9 Strategy for Spiritual Education, Catechisation and Culture $<$ http://bgpatriarshia.bg/index.php?file $=$ strategies_1.xml $>$ (Accesed on 15 April 2016).

${ }^{10}$ Guidelines on the implementation of the Strategy for Spiritual Education ... 
metropolitans, parishes and monasteries, incorporated into a well thought-out hierarchical structure whose purpose it is to activate the implementation mechanism and, ultimately, to set up a wide national network of church schools, educational centres and units for the successful implementation of the educational programme. The Strategy also outlines the principles of implementation, vision, priorities, key objectives, tasks and forms of the educational mission $^{11}$, and, taking into account the specific Bulgarian conditions, aims to incorporate all constructive ideas and practical suggestions so as to ensure its Orthodox nature, transparency, relevance, acceptance within the Church and society, and - most importantly - its implementation ${ }^{12}$.

In the accomplishment of its mission, the BOC takes account of the specific historical and social conditions and patterns of our time, as well as the trends in the contemporary development of society and state. The Church carries out its pastoral, spiritual and educational activities so as to be able to respond to and to resist the challenges to spiritual life posed by the postmodern era, such as secularism, globalisation, existential and family problems, environmental crises, separation of science and technology from Christian values, lack of spirituality of contemporary culture and youth sub-culture, and preaching of spiritual doctrines and practices which are alien to the Bulgarian cultural tradition ${ }^{13}$.

Conclusion: The development of spiritual education, Orthodox catechisation and church culture is acknowledged as a key priority in the mission of the Bulgarian Church. Through its educational and cultural work, the BOC is called upon to effectuate a new and comprehensive revival in the spiritual life of contemporary Bulgarian society ${ }^{14}$.

\footnotetext{
${ }^{11}$ Strategy for Spiritual Education, Catechisation and Culture ...

${ }^{12}$ Guidelines on the implementation of the Strategy for Spiritual Education ...

${ }^{13}$ Ibid.

${ }^{14}$ Ibid.
} 


\section{Church and Education}

As a guardian of Orthodox Bulgarians, in its educational mission, the Bulgarian Orthodox Church has always nurtured and supported the Bulgarian society, particularly at times of extreme contradiction and spiritual crisis.

The origins of Orthodox education can be traced back to church experience and are soteriological in nature. The Bulgarian Orthodox Church has a vital role in the solidification of the educational mission in Bulgarian society as creator, consolidator and keeper. Centuries ago, the Church set up the first schools in the country to instruct the people in the true knowledge of God and to bestow upon them a love of Christian virtues and honourable life. After the Liberation of 1878, this educational mission was upheld and further developed by the educational institutions in the newly established Bulgarian state.

The existence of a good modern educational system in Bulgarian schools requires that this tradition of cooperation and mutual respect be maintained. And if we are to ensure the relevance of the educational system to the current European requirements, we must grant Orthodox religious education a proper status in Bulgarian schools. ${ }^{15}$ Unfortunately, under the current legal and regulatory system, the subject is taught as an elective or an optional class, while the new Pre-School and School Education Act ${ }^{16}$, to enter into force on 1 August 2016, does not envisage any changes to this situation.

\section{Church and School}

The school is the medium through which the moral values accumulated in the course of the previous centuries are passed on to the new generations.

The Church holds the education of children to be

${ }^{15}$ Concept of the Holy Synod on the status of the subject of Religion ...

${ }^{16}$ State Gazette, issue. 79, 13 October 2015. 
"partial and incomplete if all it can offer them is a system of knowledge about the surrounding world, but where it fails to foster in them stable spiritual and moral criteria, and as long as children receive knowledge but remain unsure of how to use it towards living a dignified and prosperous life" 17 .

The purpose of education should not be just to provide information, but rather to arouse in the heart a desire for a true moral feeling of love for God, our neighbour, our homeland, and its history and culture. In this respect, the Church and the school are called upon to cooperate. The Church must support the school in its educational mission, since it is the spiritual and moral character of man on which both his personal salvation and the future of the nation and of the entire human race depend. On the other hand, the responsibility and commitment for the provision of comprehensive training to children and adolescents, including the provision of training regarding the cultural and religious tradition of the country, lies with the school.

Orthodox religious education has held a place in the Bulgarian educational system all the way since the Liberation of 1878, except for the totalitarian period between 1946 and 1989, when any form of Orthodox education was banned. After 1989, the new democratic society gradually started to restore religious education in Bulgarian schools with the direct support of the Holy Synod. In 1997, the introduction of the new subject of Religion marked the beginning of the restoration of the status of religious education ${ }^{18}$.

The education reform, launched in the 2002/2003 academic year, and the changed socio-economic characteristics of contemporary society pose upon the school the requirement to

${ }^{17}$ Letter of the Holy Synod of the BOC to the Prime Minister, Mr. Boyko Borissov, concerning the status of the subject of Religion. < http://www.bgpatriarshia.bg/news.php?id=171720> (|Accesed on 15 April 2016).

${ }_{18}$ For more on this issue see: Andrian Aleksandrov, Religious Education in Bulgaria - Past and Present, in: "Teaching Methods in Religious Education Learning by Heart or by Experience", Sofia. 2015, p. 86-96. 
respond adequately to the new challenges. The main goal of education in the Bulgarian school is the formation of a free, moral and enterprising personality ${ }^{19}$. This would be impossible to achieve without the instruction of students in the Christian Orthodox faith, traditional moral virtues and culture.

The Holy Synod of the Bulgarian Orthodox Church has repeatedly insisted that this process be brought to an end through the introduction of compulsory religious education. However, it remains just wishful thinking ${ }^{20}$.

Regardless of the ever-changing conditions in today's multicultural society, the main goal of religious education in the Bulgarian comprehensive school system according to the BOC is: Formation of spiritual culture and cultural and moral identity of students, their personal development and support for their orientation, adaptation and successful participation in contemporary society $^{21}$. The study of religion will further enrich and promote students' understanding of their own faith and culture, and will facilitate the formation of their worldview and personal growth.

The aims of the educational process are set according to age and to the prospects of students' development and improvement. The study of religion will reinforce the value system and the expansion of their spiritual and cognitive strengths by dignifying the heart and the soul, which will, in turn, enable students' lifelong personal development ${ }^{22}$.

The main purpose of religious education is to provide students with knowledge, skills, attitudes and experience based on which they can build their personalities and develop their worldviews. It will also prepare them to get a taste of and to explore the religious and moral aspects of their own lives and of the life of

\footnotetext{
${ }^{19}$ Public Education Act, Article 15 (1). <http://lex.bg/laws/ldoc/2132585473> (Accesed on 15 April 2016).

${ }^{20}$ Pre-School and School Education Act. In: State Gazette, issue 79, 13 October 2015.

${ }^{21}$ Concept of the Holy Synod on the status of the subject of Religion ... ${ }^{22}$ Ibid.
} 
society as a whole through the implementation of the following set of tasks:

1. Introduce students to the specific aspects of religion;

2. Involve students in the spiritual and cultural traditions of the country;

3. Familiarise students with other existing religions in Bulgaria and instruct them in religious tolerance;

4. Help students to understand the historical, cultural, moral and worldly importance of religion;

5. Instruct students in moral and honourable behaviour.

Considering the specific cultural and historical context in Bulgaria, the Concept of the Holy Synod on the status of the subject of Religion envisages three profiles of instruction: ReligionOrthodoxy, Religion-Islam and Religious Studies. These profiles combine the principles of confessionality (profiles one and two) and non-confessionality (profile three). The Concept further provides that each officially recognised confession may propose a profile of its own, as long as it can meet all applicable criteria ${ }^{23}$.

The purpose of the course Religion-Orthodoxy will be to strengthen and uphold students' Orthodox identity, whereas that of Religion-Islam will be to strengthen and uphold their Islamic identity.

The study of religion will help students understand the importance of religion for their own personalities, and to recognise its role and influence on the formation of society and culture.

Finally, the course Religious Studies will seek to offer students a common cultural, historical, religious and moral instruction in spiritual values in order to support their development as respectable citizens of modern-day society ${ }^{24}$.

${ }^{23}$ Concept of the Holy Synod of the BOC on the status of the subject of Religion ...

${ }^{24}$ Ibid. 


\section{Principles of the Implementation of Spiritual Education and Catechisation in Bulgaria}

The implementation of the Strategy on Spiritual education, catechisation and culture of the BOC will build on several fundamental principles ${ }^{25}$.

Christo-centrism: This is the basic fundamental, universal, meaningful and purpose-bearing principle, instructing us to relate everything in our lives and didactic work to our Lord Jesus Christ, who is the way, the truth and the life (John 14:6), and the source of all wisdom, holiness, knowledge and grace (John 1:16). This principle postulates that no private opinions, albeit of authoritative men, may be voiced during catechetical work, but that only Christ's teachings should be revealed, i.e. the truth which He bestowed upon us, or, more precisely, the truth that $\mathrm{He}$ is. Each teacher and catechist must strive towards instructing in the teachings and life of Jesus Christ, for only He is the superb teacher within the Church.

Biblical spirit: Spiritual education and catechisation must be drawn from and must draw upon Sacred Tradition and Sacred Scripture in order to retain its truthfulness and salvation as a continuation of Jesus Christ and the apostolic Gospel in our time. This requires thorough knowledge of the Bible and patristic heritage.

Canonicity: Canons are the link between the Universal Church, the local church and the organisation of each ministry within them, including all educational activities. Within the Church, the fundamental right to teach (potestas magisterii) lies with the bishop. For this reason, all spiritual teaching, catechisation and cultural work is carried out with the blessing and the participation of the bishop.

Catholicity: Proper churching is impossible without participation in the life of the parish, as, by its very nature, churching refers to one's reception in the liturgical and social life of the parish. Carrying out its educational, catechetic and cultural work, the parish is faced with two tasks: the first relates to the care that must be taken

${ }^{25}$ Guidelines on the implementation of the Strategy on Spiritual Education ... 
to deliver the experience of faith to the newly baptised Christians; and the second - to the fruitful incorporation of what they have been taught into their daily lives.

Ecclesiasticality: It refers to the revelation of the soteriological meaning of Orthodox spiritual, educational and cultural work and its administration in devotion to God and His Church. Ecclesiasticality acts as a guarantee against the departure from Christ's truth of faith by fostering the Orthodox Christian ethos through reception in the liturgical community and involvement in Orthodox life, which unfailingly observes the spirit and order of the Church.

Pastoral and hierarchical dimension: A prerequisite for the proper accomplishment of the objectives of the educational and cultural mission of the Church is that pastoral and church ministry be organised in the best manner available. This can be achieved through the acceptance of methodological, pedagogical and organisational rules ensuring the systematic and thorough administration of pastoral care and educational work within the BOC. Spiritual education, culture and instruction are the inseparable parts of a single systematic and coherent spiritual process, whose ultimate goal is to bring people to Christ.

Communality: All clergy entrusted with the higher task of instructing into the truths of the Orthodox faith and way of life must act in a spirit of cooperation and complementarity towards the accomplishment of the large-scale evangelisation, which is once again needed by the people at the dawn of the twenty-first century.

Liturgicality: Quite often, in public space, more focus is put on the perception of the Church as a national institution than as the mystical body of Christ. Hence, Divine Liturgy is commonly conceived as a ritual or as more or less equal to theatrical action. On the contrary, Divine Liturgy must be understood as the true locus of catechisation, Orthodox education, instruction and cultural work of the Church. It is necessary and important to preach the essence of 
Liturgy, so that all Christians can take a thoughtful and devout part in it in order to gain real joy of this ministry.

Gracious cooperation (synergism) or interaction between God, teacher and learner: This didactic effect is based on a sense of mutual love and co-work, and it leads to a spiritual relationship between the instructor and the instructed, nurturing them to spiritual unity, consensus and emotional harmony. This principle means that the didactic process involves a trinity of the effort made by teacher and learner in the blessing of God's grace.

Ascetic spirit: The cultural and educational work of priests, monks, nuns and laity must be the bearer of great zeal, selfabnegation, spiritual abstinence and sacrifice for the benefit of the Church and the salvation of our fellow men.

Non-ideologisation: Under no condition may the spiritual educational work of the Church be carried out under the influence of socio-political ideologies, philosophical views or scientific theories, nor may it be dominated by any form of worldly spirit. Church education and catechisation must preach and testify to the faith, whereas ideology can distort their essence and engender profanation.

Active openness to the world: Social ministry is a sign of the dynamism of the parish. Church education and catechisation will not be upheld by the social ministry of the parish if the faithful maintain an attitude of social passivity and inaction.

Continuity to ensure the persistence of the apostolic, patristic and national educational and cultural traditions, passed on from one generation to the next through the gospel of God Incarnate, and to bestow spiritual experience by means of education and mystical union with God and the other Church members.

Co-action: An active sharing of spiritual and educational duties at the institutional level between the Holy Synod, metropolitans, monasteries and parishes engaged in the practical spiritual, educational, catechistic and cultural work of the Church. This principle further includes cooperation with all institutions and structures outside the Church which support the Church's 
understanding of the meaning and the purpose of education, culture and spiritual life.

Church oikonomia through which the Holy Church incorporates in its spiritual, educational and cultural work the principle of relevance to the dynamically changing world and understanding of the spiritual needs of the people: The Bulgarian Orthodox Church, through its clergy, catechists, teachers and cultural workers, fulfils the patristic teaching that we should be unforgiving of our sins and compassionate to the shortcomings of our fellow men.

Perseverance: It suggests solidarity in the fulfilment of the planned long-term goals, priorities and tasks, leading to a purification of the heart and the life of the individual and the family, a revival of parish life and liturgical convergence of the entirety of our existence, as opposed to the formation of parachurch practices and communities.

\section{Aim and Objectives of Spiritual Education and Catechisation}

The main aim of the pastoral ministry and the spiritual education of the Church is the pursuit of the primordial providence of God for salvation through the deification of man. To achieve this, man must be cleansed, enlightened and sanctified by sacramental life in the Church.

The attainment of this fundamental goal requires the implementation of the following strategic objectives of the educational and cultural mission of the $\mathrm{Church}^{26}$ :

1. Instruction of the unbaptised and of the baptised through the unadulterated truth of God's word and education of men through the original model appearing to us in the Person of our Lord Jesus Christ.

2. Creating conditions for churching and active involvement in the life of the parish and of the entire Church of all newly baptised

${ }^{26}$ Strategy for Spiritual Education, Catechisation and Culture ... 
and of those previously baptised who remain outside the graceful sacramental life of the Orthodox Church.

3. Spiritual guidance to support Christians in the cleansing of sins, improvement of virtues and spiritual enlightenment and transformation and involvement of Christians in spiritual striving, obedient prayer in the face of God and active and devout Christian life.

4. Protection of Orthodox Christians from the influence of schisms, sects, heterodoxy, superstition and disbelief; restoration into the Church of dropouts due to participation in other religious communities, doctrines and movements; familiarisation of heterodox Christians through pure Orthodox teaching and way of life; education through evangelical light of secular people and of those who are hostile to religion.

5. Expansion and consolidation of missionary and catechetic activities as the priority mechanism of the Bulgarian Orthodox Church for the preservation and fostering of religious and patriotic consciousness in Orthodox Bulgarians.

6. Initiation and promotion of a comprehensive and systematic process for improving the qualifications and increasing the number of the active participants in the spiritual education and the cultural work of the BOC.

7. Strengthening of the influence of the Church in the field of religious education, instruction and knowledge in the general education system in Bulgaria.

8. Development and dissemination of the Orthodox culture created in the BOC.

Conclusion: The Strategy offers a solid framework for the recognition of current problems in the field of church catechisation and religious education, the identification of priorities to effectively tackle those problems, and the justification of strategic objectives, tasks and action plans establishing the measures and tools of its practical implementation. 


\section{Conclusions}

Parish catechisation is the duty of those having accepted the pastoral ministry, of priests, and, in a sense, of all Christians. At the same time, the fundamental right of each newly baptised Christian is to receive from the Church education and instruction in the basic truths of faith and morals. All of the above is indicative of the necessity and the vital role which the Church attaches to catechisation.

Statistics show that $82.6 \%$ of Bulgarians are Orthodox Christians, $1.2 \%$ are Christians of other confessions, and $12.2 \%$ are Muslim. This should mean that at least $96 \%$ of the Bulgarian population should believe in God and in the afterlife. According to a survey conducted in 2009 however, only $67.3 \%$ of Bulgarians believe in the existence of God, while $21.7 \%$ do not. At the same time, just $13.6 \%$ attend religious services at least once a month, and $24.1 \%$ declare a faith in the afterlife. ${ }^{27}$ On the one hand, this speaks of insufficient or incorrect catechisation, and, on the other - of the ever more acute and urgent need of parish catechisation.

In observance of its centuries-old tradition, the Church treats the secular school system respectfully and is willing to be involved in it guided by the recognition of personal freedom. Moreover, it alone considers the deliberate imposition of anti-religious and antiChristian ideas to students, which lead to increased hostility, hatred and violence among them. This is why the Church advocates the removal of consequences of atheistic control over the public education system. ${ }^{28}$

The Bulgarian Orthodox Church recognises the trends in the development of the social and cultural environment, the processes of

${ }^{27}$ See Александров, Андриан. Енорийската катехизация - възможности и перспективи. В сб.: „Девети Светониколаевски православни образователни четения", Бургас, 2011, с. 86.

${ }^{28}$ Concept of the Holy Synod of the BOC on the status of the subject of Religion ... 
social disintegration, and the increasing prevalence of poor spirits, unbelief, superstition and religious syncretism. For these reasons, it makes concerted effort to promote and strengthen the process of spiritual and moral healing and transformation of man and society through testimony of the Truth. To achieve this, the Church in Bulgaria mobilises its full potential for evangelisation and testimonial to the risen Lord Jesus Christ and to the way of salvation of man. In this way, the Orthodox spiritual education and catechisation carried out within the BOC becomes a fulfilment of Christ's testament and a continuation of His mission of salvation on earth.

\section{References}

1. Aleksandrov, Andrian, Religious Education in Bulgaria - Past and Present, in: "Teaching Methods in Religious Education - Learning by Heart or by Experience", Sofia. 2015.

2. Александров, Андриан. Енорийската катехизация - възможности и перспективи. В сб.: „Девети Светониколаевски православни образователни четения", Бургас, 2011.

3. Белановский, Ю. С., Ракушин, А. В., Шестаков, А. А. Катехизация в Русской Православной Церкви на современном этапе. Учебное пособие для слушателей курсов по подготовке катехизаторов, миссионеров и церковных педагогов. М. 2007.

4. Pre-School and School Education Act, in: State Gazette, issue 79, 13 October 2015.

5. European Values Study (4 $4^{\text {th }}$ wave, Bulgaria 2008) $<$ http://www.bsabg.org/index.php/2012-05-24-08-32-37/16-4-2008> (Accesed on 15 April 2016).

6. Public Education Act, Article 15

$5 \quad(1)$. $<$ http://lex.bg/laws/ldoc/2132585473> (Accesed on 15 April 2016).

7. Concept of the Holy Synod of the BOC on the status of the subject of Religion in the Bulgarian comprehensive school system $<$ http://www.bgpatriarshia.bg/index.php?file $=$ concepts_1.xml $>$ (Accesed on 15 April 2016). 
8. Strategy for Spiritual Education, Catechisation and Culture $<$ http://bg-patriarshia.bg/index.php?file=strategies_1.xml $>$ (Accesed on 15 April 2016).

9. Guidelines on the implementation of the Strategy on Spiritual Education, Catechisation and Culture of the BOC $<$ http://www.bg-patriarshia.bg/index.php?file=strategies_2.xml $>$ (Accesed on 15 April 2016).

10. Letter of the Holy Synod of the BOC to the Prime Minister, Mr. Boyko Borissov, concerning the status of the subject of Religion.<http://www.bg-Patriarshia.bg/news.php?id=171720> (Accesed on 15 April 2016). 